\title{
RAINFALL INTENSITY AND MEPIQUAT CHLORIDE PERSISTENCE IN COTTON
}

\author{
Fábio Suano de Souza ${ }^{1}$; Ciro Antonio Rosolem²* \\ ${ }^{1}$ UNESP/FCA - Programa de Pós-Graduação em Agronomia \\ ${ }^{2}$ UNESP/FCA - Depto. de Produção Vegetal, C.P. 237 - 18603-970 Botucatu, SP - Brasil. \\ *Corresponding author <rosolem@fca.unesp.br>
}

\begin{abstract}
In some regions where cotton is grown in Brazil rainfall amounts to about 2,000 mm per year, which imposes a great risk for Mepiquat Chloride (MP) to be washed from cotton leaves before being absorbed. The objective of this research was to evaluate the MC persistence when applied on cotton plants submitted to different rain intensities after spraying. The treatments were three MC rates: $0,15.0$ and $30.0 \mathrm{~g}$ a.i. $\mathrm{ha}^{-1}$ and four simulated rainfalls, applied 90 minutes after MC spraying: 5, 10, 20 and 40 $\mathrm{mm}$, plus a treatment without rain. Cotton plants of the cv. Delta Opal were grown in $12 \mathrm{~L}$ pots filled with an Haplortox. The experimental design was consisted of complete randomized blocks, in a factorial scheme, with four replicates. The evaluated parameters were: plant height, number of reproductive branches, dry matter weight, reproductive structures, retention and leaf area. The higher the rainfall the lower the effectiveness of the plant growth regulator in controlling plant height. A simulated rainfall as low as 5 $\mathrm{mm}$ occurring 90 minutes after MC application was enough to wash some of the plant growth regulator from cotton leaves.

Key words: plant growth regulator, rain washing, plant height
\end{abstract}

\section{INTENSIDADE DE CHUVA E PERSISTÊNCIA DE CLORETO DE MEPIQUAT NO ALGODOEIRO}

\begin{abstract}
RESUMO: Em parte das regiões onde se encontram as maiores áreas de algodão no Brasil atualmente, o índice pluviométrico está ao redor de $2.000 \mathrm{~mm}$ anuais, existindo risco de ocorrer lavagem do Cloreto de Mepiquat (CM) das folhas do algodoeiro antes de ser absorvido pelas plantas. O objetivo deste trabalho foi avaliar a lavagem do CM aplicado no algodoeiro por diferentes laminas de chuva simulada. Os tratamentos constaram de três doses do regulador à base de cloreto de mepiquat: $0,15.0$ e $30.0 \mathrm{~g} \mathrm{ha}^{-1} \mathrm{e}$ quatro lâminas de chuva simulada: 5, 10, 20 e $40 \mathrm{~mm}$, mais um tratamento sem chuva. Foram utilizados vasos de 12 litros de capacidade e a cultivar Delta Opal. Os parâmetros avaliados foram: altura de plantas, número de ramos reprodutivos, massa de matéria seca, retenção de estruturas reprodutivas e área foliar. Quanto maior a intensidade de chuva ocorrida após a aplicação do regulador maior foi o comprometimento da ação do produto, que repercutiu em interferência no crescimento das plantas. Chuvas de $5.0 \mathrm{~mm}$, ocorridas 90 minutos após a aplicação do cloreto de mepiquat, já causaram prejuízo na ação do produto no crescimento do algodoeiro, sendo o efeito maior com o aumento da quantidade de chuva simulada.

Palavras-chave: algodão, regulador vegetal, altura de plantas
\end{abstract}

\section{INTRODUCTION}

Cotton rank growth resulting from high soil fertility requirement and climatic conditions may decrease yields (Silva, 1981). The use of Plant Growth Regulators (PGR) like Mepiquat Chloride (MC) is one of the agronomical strategies to overcome this kind of problem (Hodges et al., 1991). Mepiquat Chloride (N,N-dimethyl-piperidinium chloride) may be included in the group of PGR that inhibits gibberellic acid biosynthesis, being, therefore, an inhibitory agent of cell expansion (Reddy et al., 1995). It is a systemic product absorbed by the green plant parts and transported through the xylem and phloem, being uniformly dis- tributed throughout the plant, and it has been admitted that the product is not degraded in cotton (Reddy et al., 1992).

Potential benefits of MC application are: reduction on plant growth and height leading to an improved architecture and increase on fruit retention at the first positions of the fruiting branches, leading to an improvement on harvest earliness and eventually on harvest efficiency and quality (Barbosa \& Castro, 1983; Kerby et al., 1986; McConell et al., 1992).

In Brazil, MP is recommended to be applied to cotton when the first flower bud from the first position reaches $3.0 \mathrm{~mm}$ in diameter. When $50 \%$ of the plants reaches this stage, rates ranging from 12.5 to 
$30.0 \mathrm{~g} \mathrm{ha}^{-1}$ of MC active ingredient should be applied (Furlani Jr. et al., 2003).

The season in which PGRs are applied to cotton in Brazil corresponds to a period of high rainfall. There is, therefore, a high risk of the product being washed off by rain before it is absorbed by the plant. Thus, it would be necessary to reapply the amount of product lost in order to guarantee the effect on plant growth control. MC losses from cotton leaves ranged from $52 \%$ with rains right after application to $28 \%$ when the rain was applied $32 \mathrm{~h}$ after MC application (Mateus et al., 2005). However, it is still not clear how the rate of MC or the amount of rain would affect product persistence on cotton leaves.

This experiment evaluated MC persistence on cotton leaves after a simulated rainfall, as well as its effects on plant growth and the amount of product to be reapplied after rain, as affected by $\mathrm{MC}$ application rates.

\section{MATERIAL AND METHODS}

An experiment was conducted in a greenhouse in Botucatu, SP, Brazil ( $\left.22^{\circ} 51^{\prime} \mathrm{S}, 48^{\circ} 26^{\prime} \mathrm{W}\right)$, in $12-\mathrm{L}$ plastic pots using soil from the ploughable layer of an Haplortox, sieved through a $4 \mathrm{~mm}$ mesh. The chemical characteristics of this soil are $\mathrm{pH} 0.01 \mathrm{~mol} \mathrm{~L}^{-1} \mathrm{Cacl}_{2}$ = 5.7; O.M. $23.4 \mathrm{~g} \mathrm{~kg}^{-1} ; \mathrm{P}=43.5 \mathrm{mg} \mathrm{dm}{ }^{-3} ; \mathrm{K}=14.0$; $\mathrm{Ca}=36.4 ; \mathrm{Mg}=12.2 ; \mathrm{H}+\mathrm{Al}=31.3 ;$ C.E.C $=94.0$ $\mathrm{mmol}_{\mathrm{c}} \mathrm{dm}-3 ; \mathrm{V} \%=67$. The soil had already received lime and fertilizers according to common practices of the São Paulo State.

Five cottonseeds of the cv. Delta Opal were pre-germinated for 36 hours in a germination chamber at $30^{\circ} \mathrm{C}$ and thereafter placed in each pot. Seeds were previously treated with fungicide. Five days after plant emergence, they were thinned to two plants per pot. After the appearance of the first true leaf and during the experiment, a complete nutrient solution (Hoagland \& Arnon, 1950) was applied weekly at a rate of $500 \mathrm{~mL} \mathrm{pot}^{-1}$. Up to flowering, a half strength solution was used and from flowering to harvest, a full strength solution was applied weekly. Nutrient solution was applied in order to overcome the restrictive effect of pot size on root growth and to avoid possible nutritional shortcomes in the period when the experiment was conducted.

Rates of MC corresponding to $0 ; 15.0$ and 30.0 $\mathrm{g} \mathrm{ha}^{-1}$ of active ingredient were applied to plants when the first flower buds appeared (Reddy et al., 1990), Which was observed 45 days after plant emergence. Ninety minutes after spraying, plants were submitted to rain intensities of 5, 10, 20 and $40 \mathrm{~mm}$. There was also a treatment with no rain application.
The equipment used to simulate rainfall and to spray the product was mounted on a metallic structure three meters high and two meters long allowing the coupling of a cart suspended $2.5 \mathrm{~m}$. Two bars are fixed to this cart; one of them supports the rain simulation system and the other holds a spray bar. The cart moves through an area of $6 \mathrm{~m}^{2}$ towards the length of the equipment.

The experimental units (pots) were arranged along the course of the simulator's bars in lines 0.90 $\mathrm{m}$ apart, simulating a population of 90,000 plants per hectare. The spray bar was equipped with four conic nozzles (Dx 8) placed $0.5 \mathrm{~m}$ over the plant canopy. The application volume of the solution was $150 \mathrm{~L} \mathrm{ha}^{-1}$. For rain simulation, the bar was placed $1.75 \mathrm{~m}$ high and equipped with 3 high-flow nozzles (TK-SS-20), spaced $0.50 \mathrm{~m}$ from each other. Shortly before the application of the PGR, the height of all plants was measured.

After treatment application, plants were grown for 36 days. Plant height was measured every three days. At harvest, the following parameters were evaluated: number of reproductive branches, dry matter mass, reproductive structures (collection of reproductive structures present in plants and counting of the lost structures) and leaf area. Leaf area was determined using an automatic area metter.

During the period in which the experiment was conducted, the maximum and minimum air temperatures inside the greenhouse were recorded for the calculation of the accumulated degree-days (DD). The mean temperature during the experiment, after the application of $\mathrm{MC}$, was $27.7^{\circ} \mathrm{C}$. For the DD calculation the base temperature of $15^{\circ} \mathrm{C}$ was considered, using the following equation: $\mathrm{DD}=(\operatorname{Tmax}-\mathrm{Tmin}) / 2-15$. Later, growth rates were calculated by deriving the equations adjusted to the growth curves.

The need to reapply the MC washed off by rain was also calculated. This calculation was based on the growth of plants taken at $250 \mathrm{DD}$, period in which the PGR could express its effect (Heitold et al., 1996). The formula used was: $\mathrm{R}=[1-(\mathrm{GC} / \mathrm{GTt})] \times \mathrm{P}$, where: $\mathrm{R}=$ rate to be reapplied in $\mathrm{mL} \mathrm{ha}{ }^{-1} ; \mathrm{GC}=$ growth of the check plot (treatment without rain application) in $\mathrm{cm}$; $\mathrm{GTt}=$ growth of treatments $(0,5,10,20,40 \mathrm{~mm})$, in $\mathrm{cm} ; \mathrm{P}=$ rate of the product, in $\mathrm{mL} \mathrm{ha} \mathrm{h}^{-1}$.

The experimental design was a complete randomized blocks with four replications, considering a factorial scheme with three doses and five rainfalls, plus a check plot with no rain application. Means were compared using the LSD test $(P<0.05)$. Whenever necessary, regression curves were adjusted. 


\section{RESULTS AND DISCUSSION}

There was a decrease in cotton leaf area when the plants treated with $30.0 \mathrm{~g} \mathrm{ha}^{-1}$ of MC received 5.0 $\mathrm{mm}$ or no rain al all (Table 1). With higher rainfall and probably due to washing of the product, no differences were observed in cotton leaf areas of the other treatments. MC may decrease cotton leaf area, depending on the rate applied and the stage of development of the plant (Barbosa \& Castro, 1983; Reddy et al., 1990; Fernandez et al., 1991). MC applied to cotton seeds can reduce plant height since plant emergence, decreasing also the number of flower buds and branches, leaf area and dry matter yield (Nagashima et al., 2005).

$\mathrm{MC}$ is known to improve fruit retention at the lowest part of the plant (Hodges et al, 1991; Wallace et al, 1993) but, generally, there were no differences on the number of reproductive structures due to rainfall or MC spray. The structures evaluated in the present work correspond to the lowest part of the plant; thus, an effect of the PGR would be expected. However, buds, flowers and bolls were jointly evaluated so that the number obtained does not represent fruit retention, what may explain the results. On the other hand, the application of PGR impaired the formation of productive branches when plants received no rain or $5.0 \mathrm{~mm}$ of rain as compared with the treatment with no MC (Table 1). This shows that the washing of the PGR from cotton leaves by rain prevents the effect of MC in decreasing the number of reproductive branches. There is evidence that the product may cause a decrease on the number of productive branches (Barbosa \& Castro, 1983; Soares, 1999). This effect depends on the PGR rate (Lamas, 2000), so that the

Table 1 - Cotton plant leaf area 81 days after plant emergence (APE), number of reproductive branches, fruiting structures (Flower buds, flowers and bolls), lost structures and plant dry weight at 90 APE, as affected by Mepiquat Chloride rates and amount of rainfall after spraying.

\begin{tabular}{|c|c|c|c|c|c|}
\hline Rate & No Rain & $5 \mathrm{~mm}$ & $10 \mathrm{~mm}$ & $20 \mathrm{~mm}$ & $40 \mathrm{~mm}$ \\
\hline & \multicolumn{5}{|c|}{ Leaf area } \\
\hline $\mathrm{g} \mathrm{ha}^{-1}$ & \multicolumn{5}{|c|}{ - } \\
\hline 0 & 3037 & 3237 & 2957 & 3033 & 3289 \\
\hline 15 & 2731 & 2991 & 3026 & 3032 & 3110 \\
\hline 30 & 2735 & 2753 & 3238 & 3671 & 3666 \\
\hline \multirow[t]{2}{*}{ LSD } & \multicolumn{5}{|c|}{$905 *$} \\
\hline & \multicolumn{5}{|c|}{ Number of reproductive structures } \\
\hline 0 & 16.0 & 18.6 & 16.8 & 15.6 & 16.8 \\
\hline 15 & 18.3 & 18.9 & 18.0 & 19.5 & 16.4 \\
\hline 30 & 17.1 & 15.9 & 15.9 & 18.3 & 17.1 \\
\hline \multirow[t]{2}{*}{ LSD } & \multicolumn{5}{|c|}{$4.6 \mathrm{~ns}$} \\
\hline & \multicolumn{5}{|c|}{ Number of reproductive branches } \\
\hline 0 & 12.5 & 11.9 & 11.9 & 12.0 & 11.8 \\
\hline 15 & 10.8 & 11.4 & 11.9 & 12.5 & 12.0 \\
\hline 30 & 11.3 & 11.0 & 11.1 & 11.9 & 11.0 \\
\hline \multirow[t]{2}{*}{ LSD } & \multicolumn{5}{|c|}{$1.1^{*}$} \\
\hline & \multicolumn{5}{|c|}{ Number of structures lost } \\
\hline 0 & 2.3 & 2.8 & 2.3 & 1.6 & 2.4 \\
\hline 15 & 2.8 & 2.8 & 2.6 & 2.6 & 2.1 \\
\hline 30 & 3.0 & 3.9 & 2.6 & 2.6 & 2.3 \\
\hline \multirow[t]{3}{*}{ LSD } & $1.4 \mathrm{~ns}$ & & & & \\
\hline & \multicolumn{5}{|c|}{ Total dry weight } \\
\hline & $-x_{2}$ & 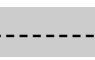 & g plant & - & -- \\
\hline 0 & 39.8 & 46.7 & 39.0 & 36.0 & 46.4 \\
\hline 15 & 39.6 & 39.7 & 40.6 & 46.8 & 48.2 \\
\hline 30 & 34.8 & 34.0 & 38.4 & 37.7 & 38.3 \\
\hline LSD & $14.6 \mathrm{~ns}$ & & & & \\
\hline
\end{tabular}

*Significant, LSD $(P<5 \%)$. ns - non significant. 
results of the present work are generally in agreement with those expected.

The number of aborted structures was decreased as rain increased (Table 1) at the highest PGR rate. Interestingly, without rain, there was no difference between this rate and the lowest rate with no PGR. Generally, cotton dry matter yield was not modified by PGR rates and rain intensities (Table 1). Athayde (1978), using chlorocolin chloride (CCC) reported that there was a reduction on plant height but the canopy dry matter remained unchanged, what was also observed in the present work. Mateus et al. (2004) had also observed no differences in dry matter yield of plants sprayed with $\mathrm{MC}$ and submitted afterwards to simulated rain at different times. According to Mateus et al. (2004), this behavior may be explained by the fact that as plants grow, there is a decrease on the leaf area ratio; in other words, PGR application caused a decrease on plant height wile dry matter production was maintained constant due to leaf thickening. Another hypothesis would be related with the increase on the photosynthetic capacity of cotton plants with less MC being washed (Stuart et al., 1984). This would be possible due to a control of the substomatic $\mathrm{CO}_{2}$ concentration causing higher carbon assimilation rates.

In relation to plant height at $0.0 \mathrm{~g} \mathrm{ha}^{-1}$ of $\mathrm{MC}$, the growth curves were quite close to each other (Figure 1, Table 2). This shows that there was no effect of the rain amount on plant growth. Since no PGR has been applied to plants in this treatment, these grew uniformly and presented no differences in relation to rain treatments. For rates of $15 \mathrm{~g} \mathrm{ha}^{-1}$ and $30 \mathrm{~g} \mathrm{ha}^{-1}$ of $\mathrm{MC}$, plants had their growth affected by the amount of simulated rainfall. The higher the rain intensity the higher the plant growth (Figure 1 and Table 2). This is a clear evidence of MC washing off the cotton leaves by the rain. While at the rate of $15 \mathrm{~g} \mathrm{ha}^{-1}$, the treatment with the highest final growth (dose of $15 \mathrm{~g} \mathrm{ha}^{-1}$, rain of $40 \mathrm{~mm}$ ) was about $70 \mathrm{~cm}$, for the treatment using 30 $\mathrm{g} \mathrm{ha}^{-1}$ and rain of $40 \mathrm{~mm}$, this growth was lower $(65 \mathrm{~cm})$.

Plant growth rates were constant along time in this experiment in pots, as it should be expected. Conversely, in an experiment conducted in pots approximately the same size as those used in this experiment, cotton growth rates decreased with time (Mateus et al., 2004), but nutrient solution was not applied, what supports the validity of applying the solution to solve this problem, common in pot experiments.

Plant height decreased with increased MC rates, as expected (Barbosa \& Castro, 1983; Reddy et al., 1992; Cia et al., 1996; Lamas, 2000) among many others. A decrease on the PGR effect as it was washed off cotton leaves by rain was also observed by Mateus et al. (2004). With rates of 15.0 and $30.0 \mathrm{~g} \mathrm{ha}^{-1}$, the washing of MC from cotton leaves followed an exponential model (Figures 2 and 3). These results are comparable to those obtained by Mateus et al. (2004), who

Table 2 - Equations fit to plant growth data, with their respective determination coefficients $\left(\mathrm{R}^{2}\right)$ and significance, as affected by Mepiquat Chloride (MC) rates and amount of rainfall after spraying.

\begin{tabular}{|c|c|c|c|}
\hline Treatment & Equation & $\mathrm{R}^{2}$ & $\mathrm{P}$ \\
\hline \multicolumn{4}{|c|}{ Without MC } \\
\hline No rain & $\mathrm{y}=4.0^{\left(-5 \mathrm{x}^{2}+0.153 \mathrm{x}-2.314\right)}$ & 0.997 & $<0.0001$ \\
\hline $5 \mathrm{~mm}$ & $y=4.0^{\left(-5 x^{2}+0.147 x+0.259\right)}$ & 0.998 & $<0.0001$ \\
\hline $10 \mathrm{~mm}$ & $y=7.0^{\left(-5 x^{2}+0.143 x+0.287\right)}$ & 0.999 & $<0.0001$ \\
\hline $20 \mathrm{~mm}$ & $\mathrm{y}=7.0^{\left(-5 \mathrm{x}^{2}+0.121 \mathrm{x}+0.553\right)}$ & 0.998 & $<0.0001$ \\
\hline $40 \mathrm{~mm}$ & $\mathrm{y}=2.0^{\left(-5 \mathrm{x}^{2}+0.148 \mathrm{x}+0.199\right)}$ & 0.998 & $<0.0001$ \\
\hline \multicolumn{4}{|c|}{$15 \mathrm{~g} \mathrm{ha}^{-1}$} \\
\hline No rain & $\mathrm{y}=6.0^{\left(-5 \mathrm{x}^{2}+0.079 \mathrm{x}-0.042\right)}$ & 0.994 & $<0.0001$ \\
\hline $5 \mathrm{~mm}$ & $\mathrm{y}=9.0^{\left(-5 \mathrm{x}^{2}+0.099 \mathrm{x}-0.964\right)}$ & 0.991 & $<0.0001$ \\
\hline $10 \mathrm{~mm}$ & $\mathrm{y}=9.0^{\left(-5 \mathrm{x}^{2}+0.111 \mathrm{x}+0.251\right)}$ & 0.998 & $<0.0001$ \\
\hline $20 \mathrm{~mm}$ & $y=9.0^{\left(-5 x^{2}+0.125 x+0.082\right)}$ & 0.998 & $<0.0001$ \\
\hline $40 \mathrm{~mm}$ & $\mathrm{y}=5.0^{\left(-5 \mathrm{x}^{2}+0.154 \mathrm{x}-1.921\right)}$ & 0.996 & $<0.0001$ \\
\hline \multicolumn{4}{|c|}{$30 \mathrm{~g} \mathrm{ha}^{-1}$} \\
\hline No rain & $\mathrm{y}=0.0001 \mathrm{x}^{2}+0.041 \mathrm{x}+0.162$ & 0.994 & $<0.0001$ \\
\hline $5 \mathrm{~mm}$ & $\mathrm{y}=7.0^{\left(-5 \mathrm{x}^{2}+0.090 \mathrm{x}+1.087\right)}$ & 0.997 & $<0.0001$ \\
\hline $10 \mathrm{~mm}$ & $\mathrm{y}=8.0^{\left(-5 \mathrm{x}^{2}+0.108 \mathrm{x}-1.519\right)}$ & 0.990 & $<0.0001$ \\
\hline $20 \mathrm{~mm}$ & $\mathrm{y}=5.0^{\left(-5 \mathrm{x}^{2}+0.135 \mathrm{x}-2.986\right)}$ & 0.986 & $<0.0001$ \\
\hline $40 \mathrm{~mm}$ & $\mathrm{y}=5.0^{\left(-6 \mathrm{x}^{2}+0.161 \mathrm{x}-3.378\right)}$ & 0.991 & $<0.0001$ \\
\hline
\end{tabular}



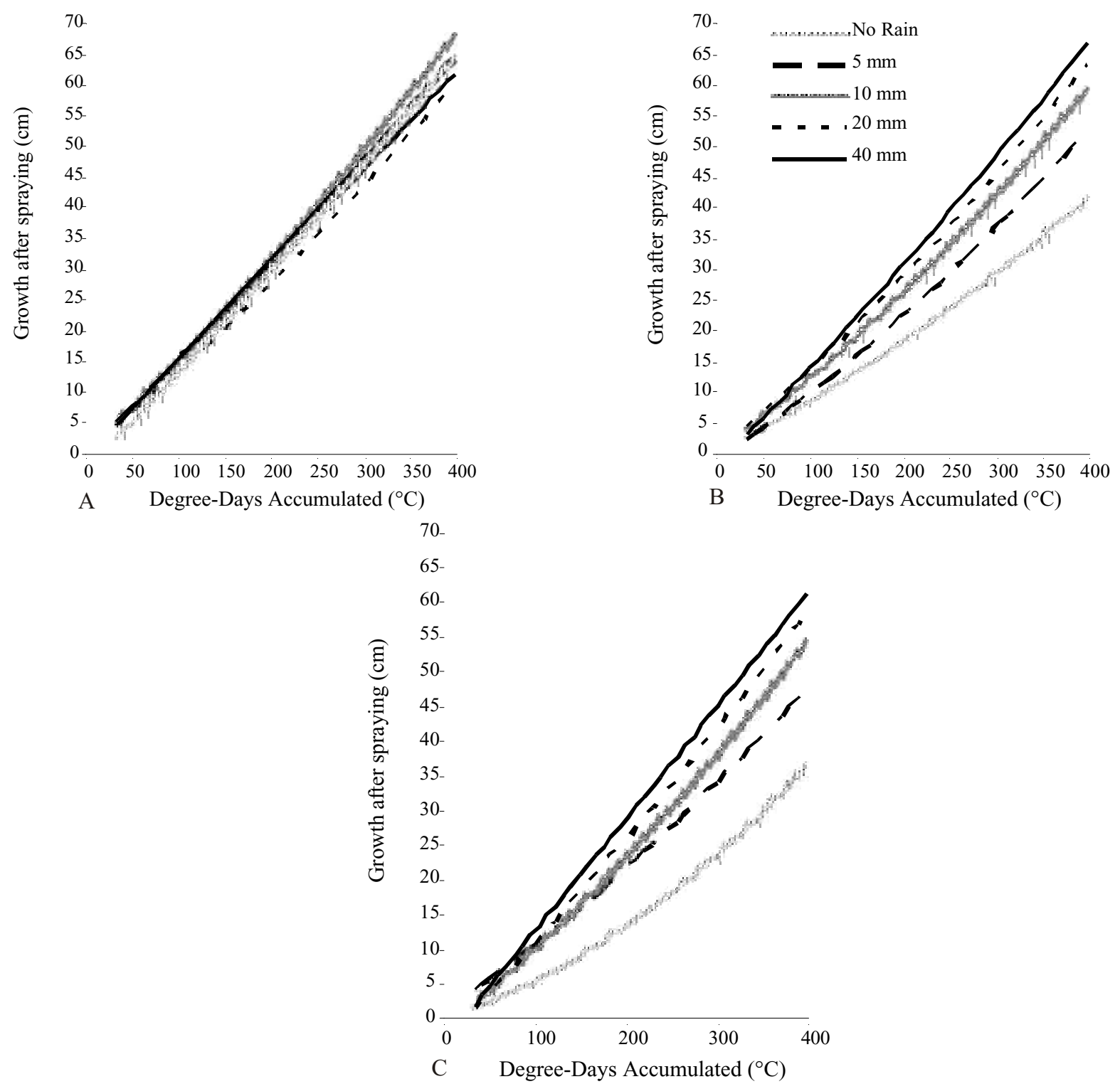

Figure 1- Growth of cotton plants after treatment application as affected by Mepiquat Chloride (MC)and rainfall 90 minutes after spraying.(A) without MC, (B) $15 \mathrm{~g} \mathrm{ha}^{-1}$ of $\mathrm{MC}$ and (C) $30 \mathrm{~g} \mathrm{ha}^{-1}$ of $\mathrm{MC}$.

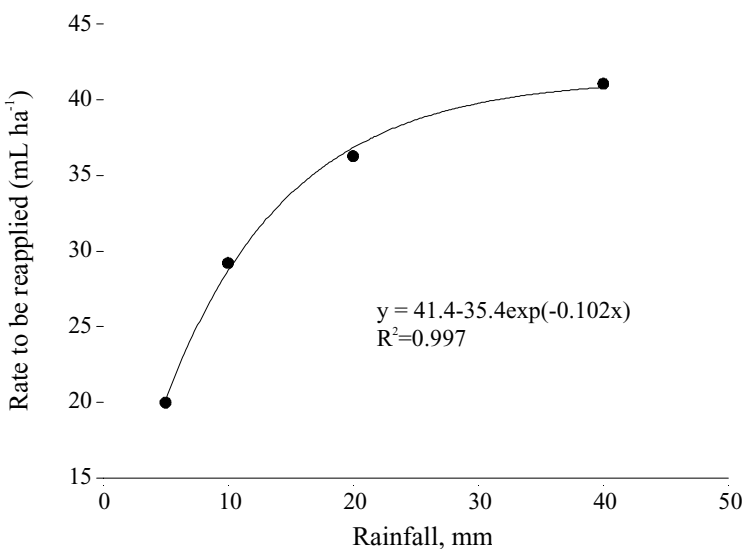

Figure 2 - Estimate of the rate of Mepiquat Chloride (commercial product with $50 \mathrm{~g} \mathrm{~L}^{-1}$ a.i.) to be reapplied as affected by the amount of rain after the product application $\left(15 \mathrm{~g} \mathrm{ha}^{-1}\right)$.

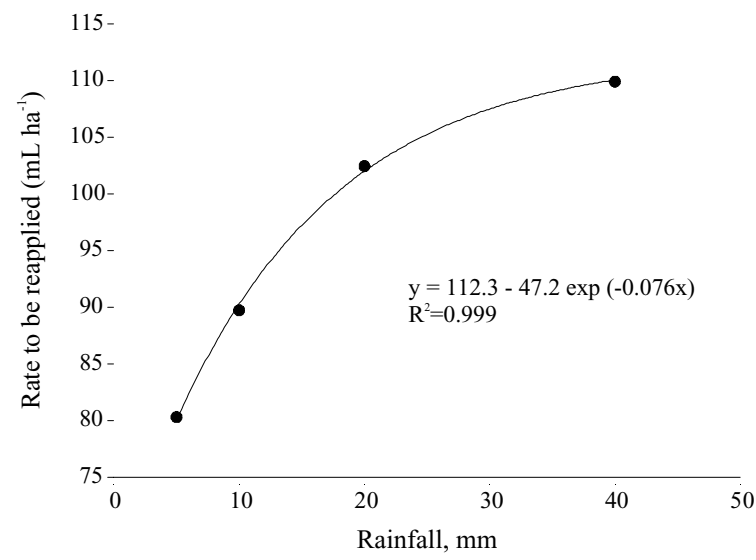

Figure 3 - Estimate of the rate of Mepiquat Chloride (commercial product with $50 \mathrm{~g} \mathrm{~L}^{-1}$ a.i.) to be reapplied as affected by the amount of rain after the product application $\left(30 \mathrm{~g} \mathrm{ha}^{-1}\right)$. 
Table 3 - Need of reapplication of Mepiquat Chloride (commercial product with $50 \mathrm{~g} \mathrm{~L} \mathrm{~L}^{-1}$ a.i.) as affected by rainfall.

\begin{tabular}{lcc}
\hline \multirow{2}{*}{ Rainfall } & \multicolumn{2}{c}{ Rate to be reapplied } \\
\cline { 2 - 3 } & $15 \mathrm{~g} \mathrm{ha}^{-1}$ & $30 \mathrm{~g} \mathrm{ha}^{-1}$ \\
\hline $\mathrm{mm}$ & 20.0 & 40.1 \\
\hline 5 & 29.2 & 44.9 \\
20 & 36.3 & 51.2 \\
40 & 41.1 & 55.0 \\
\hline
\end{tabular}

used the rate of $250 \mathrm{~mL} \mathrm{ha}^{-1}$ of a product with $50 \mathrm{~g} \mathrm{~L}^{-1}$ of a.i. Mateus et al. (2004) verified that the amount of $\mathrm{MC}$ washed off the leaves decreased as time elapsed between the application of the product and the simulated rain decreased. Thus, it is expected that the higher the rainfall the higher the rate of $\mathrm{MC}$ to be applied to reach the desirable plant growth rate. This may be attributed to a higher amount of PGR being washed off the cotton leaves in treatments in which the simulated rain was applied right after the product was sprayed, leaving no long enough time for its absorption (Mateus et al.,2004).

MC losses are proportionally higher at high spraying rates (Table 3), what suggests that higher PGR concentrations may take longer to be fully absorbed. Therefore, an intense rainfall occurring right after product application at a high dosage will have a proportionally higher effect than a lower dosage. Such results are in agreement with those obtained by Mateus et al. (2004), who studied the effect of different rain intensities using $12.5 \mathrm{~g} \mathrm{ha}^{-1}$ of MC and observed the same behavior as that obtained in the present experiment for rates of 15.0 and $30 \mathrm{~g} \mathrm{ha}^{-1}$. Considering the results obtained by Mateus et al. (2004) and those obtained in the present experiment, it is possible to infer that the higher the amount of rain and MC dosage the higher will be the need for product reposition.

\section{CONCLUSIONS}

A rainfall as low as $5.0 \mathrm{~mm}$ occurring $90 \mathrm{~min}$ utes after Mepiquat Chloride spray was enough to wash some off the product from cotton leaves, interfering with plant growth. The higher the rainfall after mepiquat chloride application on cotton the lower the effectiveness of the plant growth regulater PGR, which is directly related to plant growth.

\section{REFERENCES}

ATHAIDE, M.L.F. Efeito do CCC no algodoeiro (Gossypium hirsutum L.). Piracicaba: USP/ESALQ, 1978. 51p. (Mestrado em Energia na Agricultura).
BARBOSA, L.M.; CASTRO, P.R.C. Comparação entre diferentes concentrações e épocas de aplicação de cloreto de mepiquat, cloreto de clorocolina e ethephon em algodoeiro (Gossypium hirsutum L.) cv. IAC 17. Planta Daninha, v.6, p.1-10, 1983.

CIA, E.; ALLEONI, L.R.F.; FERRAZ, C.A.M.; FUZZATO, M.G.; KONDO, J.I.; CARVALHO, L.H.; CHIAVEGATO, E.J.; SABINO, N.P. Densidade de plantio associada ao uso de regulador de crescimento na cultura do algodoeiro. Bragantia, v.55, p.309-316, 1996.

FERNANDEZ, C.J.; COTHREN, J.T.; McINNES, K.J. Partitioning of biomass in well-watered and water-stressed cotton plants treated with mepiquat chloride. Crop Science, v.31, p.1224-1228, 1991.

FURLANI JUNIOR, E.; SILVA, N.M.; CARVALHO, L.H.; BORTOLETTO, N.; SABINO, J.C.; BOLONHEZI, D. Modos de aplicação de regulador vegetal no algodoeiro, cultivar IAC-22, em diferentes densidades populacionais e níveis de nitrogênio em cobertura. Bragantia, v.62, p.227-233, 2003.

HEITHOLD, J.J.; MEREDITH JR., W.R.; WILLIFORD, R. Comparison of cotton genotypes varying in canopy characteristics in $76-\mathrm{cm}$ vs. 102-cm rows. Crop Science, v.36, p.955-960, 1996.

HOAGLAND, D.R.; ARNON, D. The water - culture methods for growing plants without soil. Berkeley: California Agricultural Experiment Station, 1950. 32p.

HODGES, H.F.; REDDY, V.R.; REDDY, K.R. Mepiquat chloride and temperature effects on photosynthesis and respiration of fruiting cotton. Crop Science, v.31, p.1301-1308, 1991.

KERBY, T.A.; HAKE, K.; KEELEY, M. Cotton fruiting modification with mepiquat chloride. Agronomy Journal, v.78, p.907-912, 1986.

LAMAS F.M. Reações do algodoeiro CNPA_ITA 90 ao cloreto de mepiquat. Pesquisa Agropecuária Brasileira, v.35, p.507-516, 2000.

MATEUS, G. P.; LIMA, E.V.; ROSOLEM, C.A. Perdas de Cloreto de Mepiquat no algodoeiro por chuva simulada. Pesquisa Agropecuária Brasileira, v.39, p.631-636, 2004.

McCONNEL, J.S.; BAKER, W.H.; FRIZZELL, B.S.; VARVIL, J.J. Response of cotton to nitrogen fertilization and early multiple applications of mepiquat chloride. Journal of Plant Nutrition, v.15, p.457-468, 1992.

NAGASHIMA， G.T.; MARUR， C.J.; YAMAOKA， R.S.; MIGLIORANZA, E. Development of cotton plant from seeds soaked with mepiquat chloride. Pesquisa Agropecuária Brasileira. v.40. p.943-946, 2005.

REDDY, V.R.; BAKER, D.N.; HODGES, H.F. Temperature and mepiquat chloride on cotton canopy architecture. Agronomy Journal, v.82, p.190-195, 1990.

REDDY, V.R.; TRENT, A.; ACOCK, B. Mepiquat chloride and irrigation versus cotton growth and development. Agronomy Journal, v.84, p.930-933, 1992.

REDDY, K.R.; BOONE, M.L.; REDDY, A.R.; HODGES, H.F.; TURNER, B.; Mc KINION, J. Developing and validating a model for a plant growth regulator. Agronomy Journal, v.87, p.1100-1105, 1995.

SILVA, R.J.M. Observações preliminares do comportamento do cloreto de mepiquat em algodoeiro herbáceo no estado de Goiás. Goiânia: Empresa Goiana de Pesquisa Agropecuária, 1981. (Comunicado Técnico-Científico, 5).

SOARES, J.J. Fitorreguladores e remoção da gema apical no desenvolvimento do algodoeiro. Scientia Agricola, v.56, p.627-630, 1999.

STUART, B.L.; ISBELL, V.R.; WENDT, C.W.; ABERNATHY, J.R. Modification of cotton relations and growth with mepiquat chloride. Agronomy Journal, v.76, p.651-655, 1984.

WALLACE, T.P.; SNIPES, C.E.; WHITE, B.W. Effects of singlemultiple applications of mepiquat chloride on Mississip cotton. Mississipi: Mississipi Agricultural Foresty Experiment Station, 1993. 5p. (Research Reports, 18). 